\title{
ENTREPRENEURS TRAINING FEATURES IN STEM PUBLIC HIGHER EDUCATION INSTITUTIONS. CORRELATED ANALYSIS IN ECUADORIAN CONTEXT
}

\author{
M.S. Vásquez ${ }^{1}$, M.R. Perello² ${ }^{2}$ J. Cachago ${ }^{1}$ \\ ${ }^{1}$ Escuela Politécnica Nacional (ECUADOR) \\ ${ }^{2}$ Universidad Politécnica de Valencia (SPAIN)
}

\begin{abstract}
The Ecuadorian society, as it occurs in other Latin American ones, is characterized by economic, social, cultural, and educational inequalities. In order to cope with this reality, in recent years, Ecuador has been working to change the model of wealth accumulation. This challenge implies moving from an outward development model to an endogenous model based on the production of goods with higher added value. In so doing, encouraging innovation and entrepreneurship become essential to generate economic growth all along with the country.

Public universities are an essential support to regional and local development. In fact, there is a responsibility for public universities to promote, not only knowledge transfer to the students through the teaching programs, but also the development of concrete transversal skills including entrepreneurship, innovation, and social commitment. All these actions should be bounded by local governments and productive sectors to achieve the so desired economic growth. However, nowadays the knowledge acquired by students during their university studies is hardly transferred to the productive and social sphere. One of the first steps to analyzing the reasons for failure is to characterize entrepreneur students in Higher Education Institutions (HEI).

This piece of research shows the results of the characterization of entrepreneurial students in Ecuadorian public universities. A survey validated by experts has been carried out. The study is focused on determining the entrepreneurial activities and the demographic characteristics of the students in science, technological, engineering, and mathematics (STEM) public HEI in Quito.
\end{abstract}

The results of the study show low levels of entrepreneurship among the sample and a significant relationship between entrepreneurial activity and demographic characteristics of students.

Keywords: Entrepreneurship, STEM education, STEM experiences, Ecuador.

\section{INTRODUCTION}

Entrepreneurship is one of the main axes for the progress of a country, as it is the engine of the economy to generate jobs, innovation, and diversification of the production fabric [1]. However, in the special report presented in the Global Entrepreneurship Monitor (GEM) "A global perspective on entrepreneurial education and training," it is suggested that more investment in entrepreneurial training in Latin America and the Caribbean will not result in an increase in entrepreneurial activity, if innovation is not considered as the basis of entrepreneurship. [2], [3].

According to Mesías [4], "Ecuador occupies the third place in Latin American entrepreneurship efforts," but most of it is informal and not original, which would explain the high early mortality rate [1]. For this reason, as national priorities, Ecuador has considered changing its model of accumulation of wealth, which implies moving from an outward development model, based on the export of primary goods, to an endogenous model based on the production of products with higher added value, including innovation as the primary factor for entrepreneurship.

The university as a complex organism must be a space of intelligence, generation of critical thinking, and articulation between science and social problems. Thus, Higher Education Institutions have adopted a new model called the entrepreneurial university to generate transversal actions such as entrepreneurship, innovation and social commitment between universities, research centers, public administration and companies [5].

In this sense, agreeing with Poveda Morales, Alvarez Gomez, \& Vega Falcon [6] who define entrepreneurship as "as a dynamic process of vision, change and creation that requires the application 
of energy and passion for the implementation of new ideas and creative solutions", universities in their entrepreneurial role need to develop attitudes and skills such as creativity, leadership, risk predisposition, among others, in their students to meet the aforementioned objective.

Although, personal characteristics or features of an entrepreneur's profile have been mentioned by several authors (e.g. Elenurm, 2012; Greene, 2011; Zacharakis et al., 2011; Anderson, 2010; Bygrave and Zacharakis, 2010; Carey and Matlay, 2010; Duening, 2010; Rae, 2007) [7], the most named characteristics are creativity, initiative, self-confidence, energy and work capacity, perseverance, leadership, risk acceptance, need for achievement, tolerance for change and problem management.

In this context, this research is a contribution to characterize the students of the Escuela Politecnica Nacional (EPN) as future entrepreneurs. Then identify their skills considering the main characteristics of the entrepreneur profile mentioned above, and thus be able to highlight in which EPN should strengthen through transversal activities. This research was carried out with the participation of the students of the Engineering, Technology and Administrative Sciences careers.

The following structure is proposed to achieve this purpose: Introduction, Methodology, Results, Conclusions, and References.

\section{METHODOLOGY}

Next, the methodology used for the development of the research is presented in two phases. In the first stage, we established the credibility of the instrument, and in the second, we surveyed to evaluate the entrepreneurial characteristics of the students.

\subsection{Stage 1: Validation of the instrument}

\subsubsection{Instrument Construction}

The survey was prepared in two parts. The first part studies the demographic aspects, the development of ventures, and the perceptions about the needs and expectations for start-ups. For this, 130 questions of these areas were developed and subsequently validated by experts.

The second part of the questionnaire allows quantifying the level of some characteristics of the entrepreneur. For this purpose, the questionnaire posed by Rafael Alcaraz Rodríguez [7] called "Inventory of the Entrepreneur Profile" was applied. This questionnaire has 50 questions with answers on a scale from 1 to 5 to determine the predisposition of the respondent to specific situations and in this way, evaluate the features.

\subsubsection{Instrument Validation}

The instrument was validated in the same way in two parts. The first part corresponding to demographic aspects, ventures, needs, and expectations, was evaluated by an expert panel. The panel consisted of three teachers from the Faculty of Administrative Sciences of the EPN. The teachers are members of the Multidisciplinary Research Group on Information Systems, Technology, and Innovation Management and are familiar with the contents of the questionnaire and have experience in the construction of surveys.

Each member was given the questionnaire with the questions in an evaluation sheet together with the research objectives. The rubric seeks to measure the clarity in writing, coherence with the aim, if induction is made to the response, the appropriate language with the level of the informant and if it measures what it intends to measure. Finally, experts were asked to evaluate each question by answering yes or no, in the mentioned aspects.

The second part of the questionnaire about the characteristics of the entrepreneur is a questionnaire previously statistically validated through Cronbach's Alpha and T-test. [7]

\subsection{Stage 2: Testing Entrepreneurial Capacities}

\subsubsection{The sample}

The sample size was calculated not probabilistically using the quota technique, obtaining a sample of 104 students belonging to the careers as shown in Table 1 . 
Table 1. Student's Careers

\begin{tabular}{l|c}
\hline \multicolumn{1}{c|}{ Career } & Number of Students \\
\hline Business Engineering & 44 \\
\hline Electromechanical Technology & 7 \\
\hline Environmental Engineering & 1 \\
\hline Networks and Telecommunications Technology & 10 \\
\hline Software Development Technology & 7 \\
\hline Systems Engineering & 23 \\
\hline Water and Environmental Sanitation Technology & 12 \\
\hline TOTAL & 104 \\
\hline \hline
\end{tabular}

\subsubsection{Procedure}

Once the questionnaire was validated, we proceeded to create a form in google forms with the questions, whose link was shared with the students via email. Finally, the information collected was preceded to tabulate the data through the SPSS system.

\section{RESULTS}

The results of the research will be presented based on the objectives, summarizing the variables used to evaluate each section.

\subsection{Demographic Characteristics}

The students surveyed on average are 22 years old, $55 \%$ of them were men and $45 \%$ women. Of the total respondents, $1 \%$ are in free union, $2 \%$ divorced, $3 \%$ married, and $94 \%$ single. Only $2 \%$ of students have children, and $3 \%$ are foreigners.

Regarding their income level, 82\% of students earn less than 394 USD per month, 14\% between 395 and 788 USD, and only $4 \%$ earn more than 788 USD.

Of the 104 respondents, eight currently have a start-up, one woman, seven men of which $54 \%$ earn less than 394 USD per month, $23 \%$ up to 788 USD and only $8 \%$ corresponding to one entrepreneur earns more than 789 USD.

In addition to the eight entrepreneurs, six more students are working in a dependency relationship.

All respondents live in Quito.

\subsection{Entrepreneurial Activities}

The study showed that 8 out of 104 students have some entrepreneurship, which represents $8 \%$ of the sample. Six are from the Business Engineering degree and two from the Water and Sanitation Technology. However, since one of them did not show that it created, transformed, renewed, or improved any new product or service, production process or business model, it will not be considered for this study.

On the other hand, it was found that seven patents have been registered, of which one gave rise to a business.

The operating time of the enterprises indicates that three enterprises have less than one year of operation, two have between one and three years and two enterprises for more than three years.

The origin of the start-ups are mostly family ventures for family ideas or inheritance ( 5 in total), and only two are for new business ideas. 
The enterprises have a minimum staff of fewer than nine employees, and invoice less than USD 100,000 per year.

The students' perception of the influence of their parents, siblings, friends, classmates, and professors to have entrepreneurship is conceived as motivational since they consider that they all encourage them to begin with a start-up. However, they do not count on their help.

The primary motivation of these students is the independence to make their own decisions and being their own boss, followed by helping others and thirdly personal improvement.

On the other hand, Fig. 1 shows the critical aspects of the start-ups and entrepreneurship legally constituted. It is observed that the characteristics: Support policies for the entrepreneur, Access to technology, Access to national nor international markets, Tax incentives, Creation of inclusive spaces to offer entrepreneurial products, Institutional support, are considered more important in the Start-Up stage. While the characteristics: Contact networks, Availability of raw material and suppliers, Availability of machinery or tools, Access to financing, Training / Advice, Qualified human talent, Valuation of the entrepreneur in society, are considered necessary for both stages of a venture, startup and development, and operation.

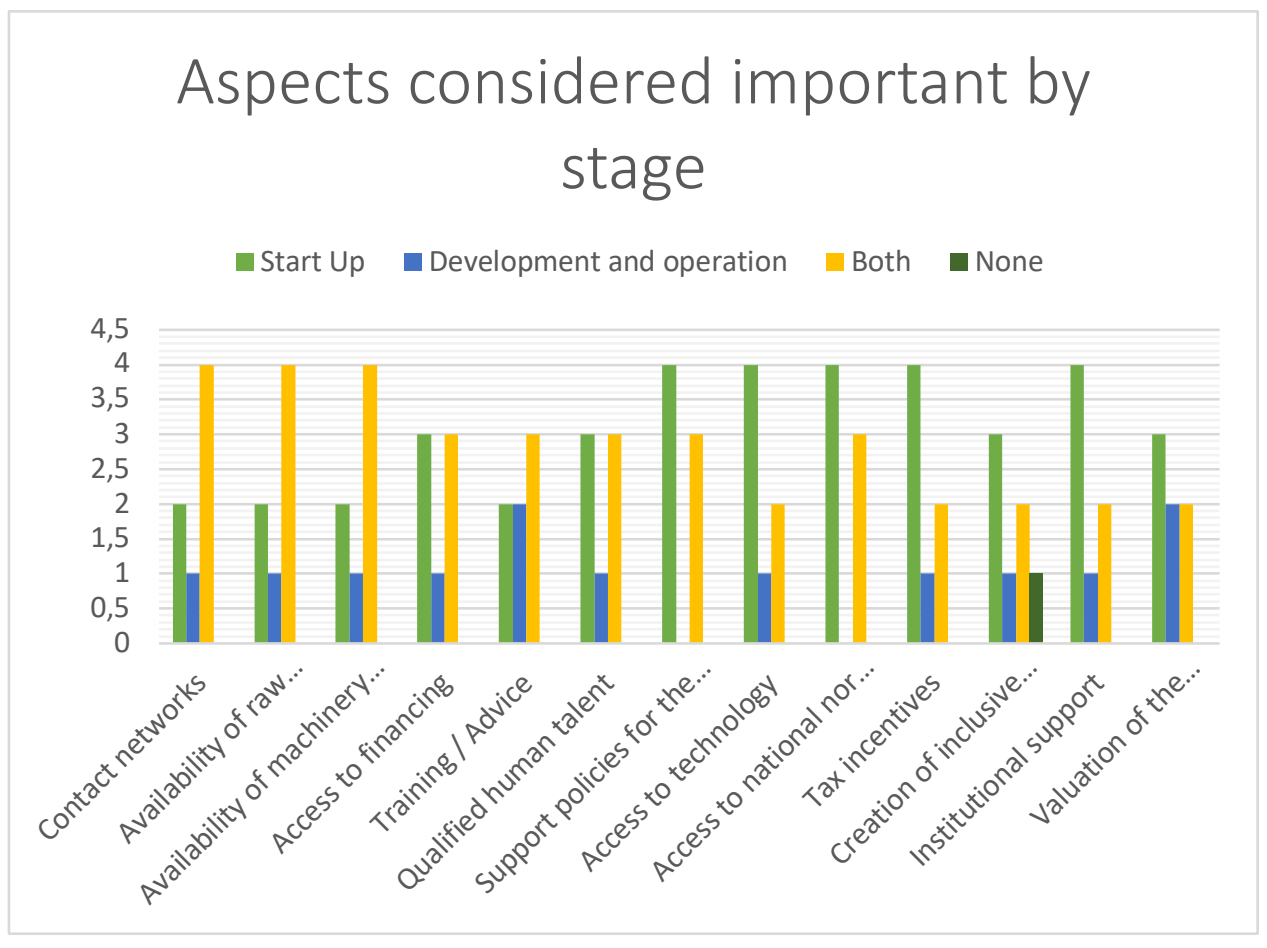

Figure 1. Aspects by stage

As for expectations, students with start-ups will mostly seek to expand internationally with their existing products and services. However, they are not interested in doing it nationally, nor creating new products or services, franchising, or merging with other companies.

Regarding the needs to start a business, students determined the levels of needs. The result of this research is shown in Fig. 2, in which all elements are highly required because they are considered necessary or very necessary. 


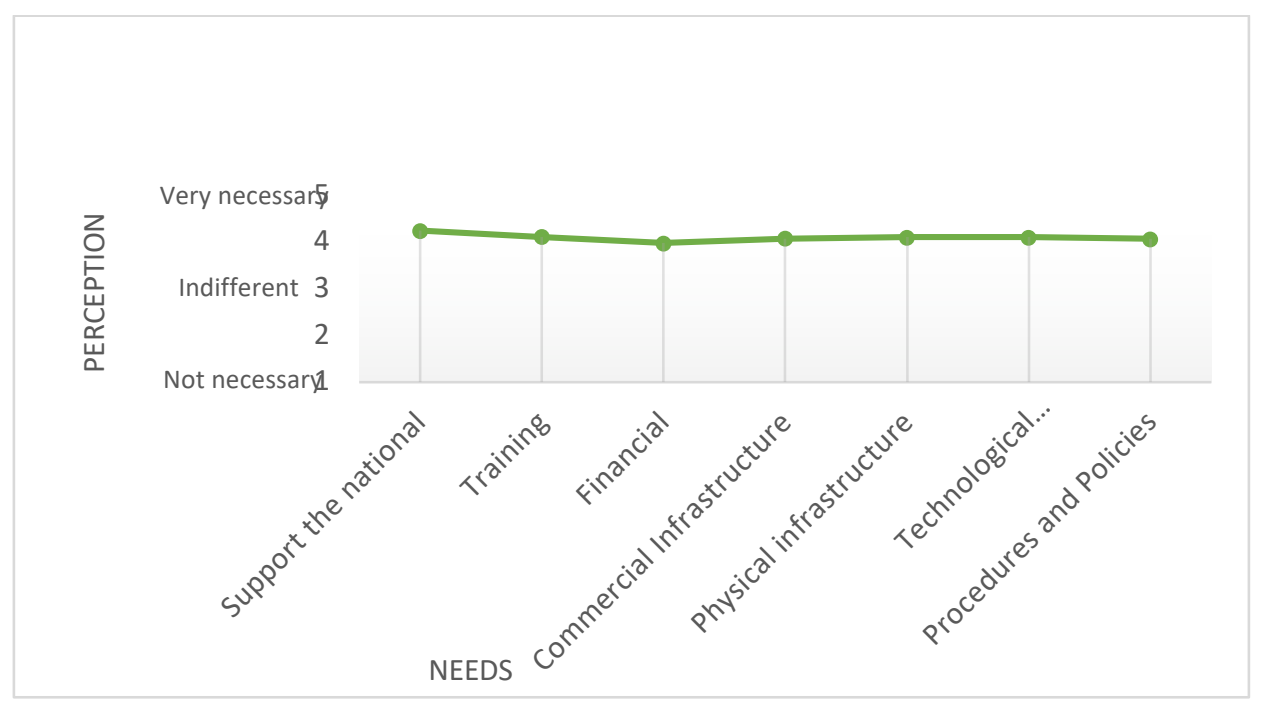

Figure 2. Perception of Needs.

Finally, students perceive that programs to encourage the creation and growth of new businesses exist, but they are not enough. Universities and higher education centers do not entirely provide adequate and quality preparation for setting up new companies and the development of established ones. New technologies, science, and other knowledge are not correctly transferred from universities and public research centers to new and growing businesses. Company and academy must work together, to identify needs and opportunities, establish agreements, links, and synergies with the concept of innovation as a base. However, they agree that it is a priority in Municipalities and Government policy the support for new and growing companies. Finally, they consider that public and private organizations provide business development services that foster development and growth.

\subsection{Entrepreneur Profile}

The results of the entrepreneur profile are disaggregated by sex and also consider the total average per characteristic. Fig. 3 shows that women present higher levels in the attributes of perseverance, achievement, and self-confidence, while men with a less noticeable difference, stand out in leadership. In the rest of the characteristics both show the same score levels.

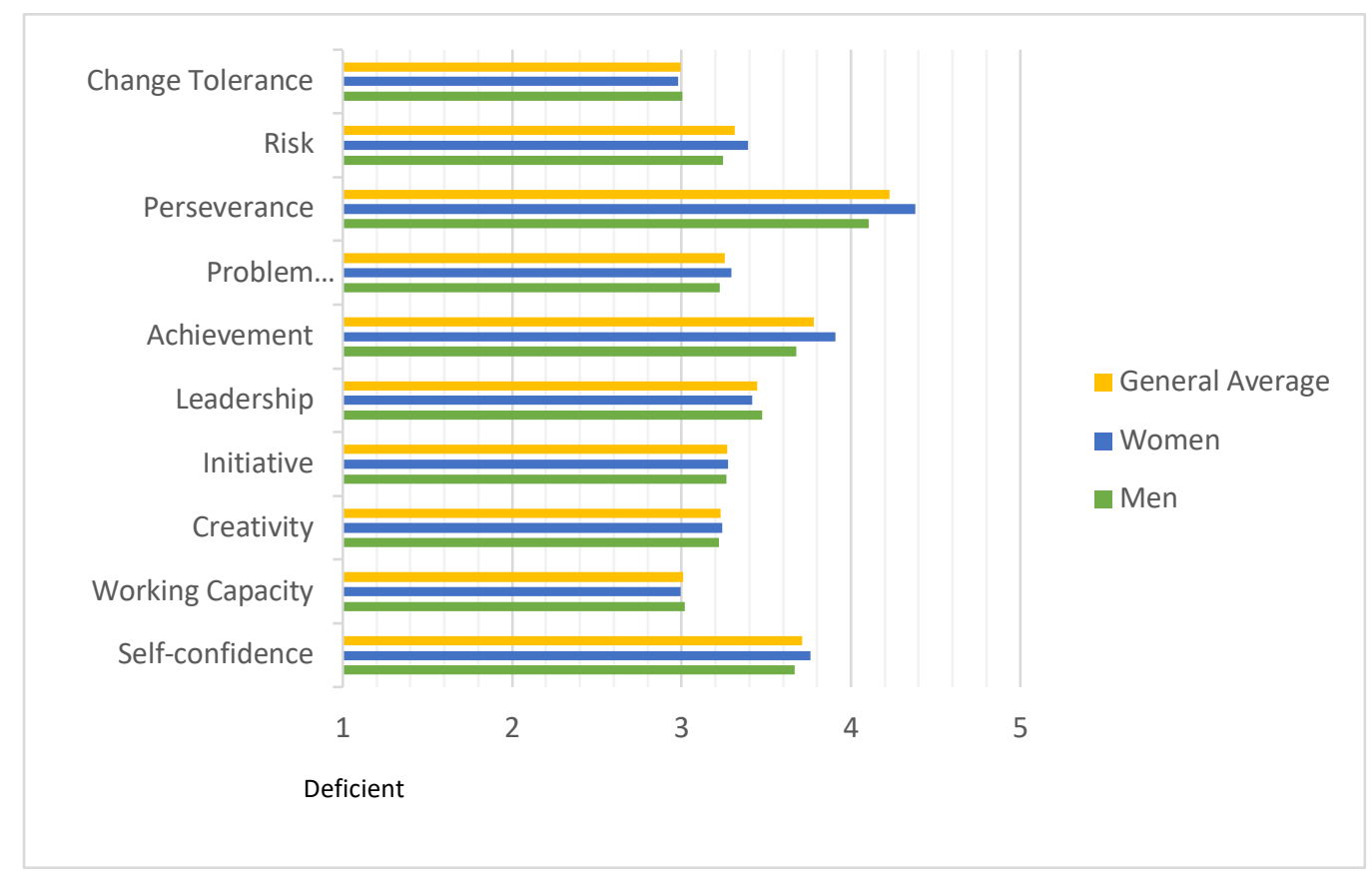

Figure 3. Entrepreneur Characteristics. 


\section{CONCLUSIONS}

The $8 \%$ of students that correspond to 1 of every 13 students have a start-up in the EPN. This percentage represents a low level considering that the current role of the university as an entrepreneurial university should encourage entrepreneurship. However, this rate is much lower than the percentage of nascent enterprises according to the GEM [2], where it figures that $22.4 \%$ of the Ecuadorian population has a start-up.

Although 13 students have a start-up, only 4 of them consider it as formal work. The students' perception indicates that entrepreneurship, while not giving them a representative salary, is more a hobby or a sporadic activity in which they are not willing to spend a lot of time and effort.

Out of the seven patents reported, only one has been commercialized, which denotes the lack of knowledge of students to move from the development of products or services to a business model. This statement is also supported because from the seven start-ups, five correspond to business students and last two to students of water and environmental sanitation technology when in total the sample was collected from seven different STEAM careers.

The perception of the students about the current environment reveals the lack of confidence in the Ecuadorian reality. They state that to start a business, they need support in all the needs suggested in this research, which reflects the fact that current enterprises do not seek to grow or diversify nationally.

According to the students' perception, the EPN does not have enough programs or curricular activities that encourage the creation of new companies or provide them tools to identify market needs and opportunities that they can satisfy with their technical knowledge.

The students of the EPN, in terms of characteristics of the entrepreneurial profile score above the average. However, the level reached does not exceed the acceptable range except for the component "perseverance" score, which tends to be outstanding. This result indicates that at the institutional level, EPN must work to improve and develop the entrepreneurial characteristics of its students.

\section{REFERENCES}

[1] L. Vicens and S. Grullon, "Innovación y Emprendimiento Un modelo basado en el desarrollo del emprendedor," Innovación y Emprend., p. 31, 2011.

[2] J. M. Dominguez, C. Muñoz, and X. Ordeñana, "Global entrepreneurship monitor ecuador 2016," 2016.

[3] A. Coduras, J. Levie, D. J. Kelley, R. J. Saemundsson, and T. Schott, "Una perspectiva global sobre la educación y formación emprendedora," 2010.

[4] R. Mesías, "Situación Del Emprendimiento Y Sus Alcances En El Ecuador," Eur. Sci. J., vol. 13, no. 13, pp. 229-239, 2017.

[5] A. González, "La Universidad como factor de desarrollo local sostenible," Ra Ximhai, vol. 9, no. 1, 2012.

[6] T. Poveda Morales, G. Alvarez Gomez, and V. Vega Falcon, Generalidades Sobre el Emprendimiento, no. March. 2019.

[7] R. Alcaraz, "Efectividad del Curso de Emprendedores, en el desarrollo del perfil emprendedor del alumno," Mtyitesmmx, no. Or 00802, pp. 1-27, 2004. 